\title{
In vitro effects of cadmium and mercury on Pacific oyster, Crassostrea gigas (Thunberg), haemocytes
}

\author{
B. Gagnaire ${ }^{a}, H$. Thomas-Guyon ${ }^{b}$ and T. Renault ${ }^{a *}$
}

\author{
a IFREMER, Laboratoire de Génétique et Pathologie (LGP), 17390, La Tremblade, France \\ ${ }^{\mathrm{b}}$ Université de La Rochelle, Laboratoire de Biologie et Environnement Marin (LBEM), avenue Michel \\ Crépeau, 17042, La Rochelle, France
}

* trenault@ifremer.fr IFREMER, Laboratoire de Génétique et Pathologie (LPG), 17390 La Tremblade, France. Tel.: +33-5-46-36-98-41; fax: +33-5-46-36-37-51.

\begin{abstract}
In the past decades, shellfish culture has developed in a significant way around the world. However, culture areas are often subject to recurring anthropic pollution. The recrudescent presence of industrial wastes is a source of heavy metals and results in pollutant transfer towards the aquatic environment in estuarine areas. Because of their mode of life, bivalves, including mussels and oysters, are suggested as ideal indicator organisms. The development of techniques allowing the analysis of the effects of pollutants on bivalve biology may lead to the monitoring of pollutant transfer in estuarine areas. In this context, the effects of cadmium and mercury on defence mechanisms were analysed in Pacific oysters, Crassostrea gigas. Pollutant effects were tested in vitro on oyster haemocytes. Cell viability and enzymatic activities (esterase, peroxidase, aminopeptidase, phagocytosis activities) were monitored by flow cytometry. Enzymatic phenoloxidase-like activity was also evaluated by spectrophotometry. High pollutant concentrations were used in order to detect the acute effect and to approach real pollutant concentrations existing in animal tissues. Cadmium induced no effect on oyster haemocytes under the tested conditions. On the contrary, mercury caused a significant haemocyte mortality after a $24 \mathrm{~h}$ in vitro incubation. Aminopeptidase positive cell percentage was enhanced by the pollutant, and phenoloxidase-like activity was inhibited. These in vitro results show that mercury may be expected to have an impact on bivalve immune functions in contaminated areas.
\end{abstract}

Keywords: Author Keywords: Crassostrea gigas; Haemocytes; Flow cytometry; Cadmium; Mercury; Phenoloxidase; Cellular activities; Toxicity 


\section{INTRODUCTION}

For several decades, shellfish culture has developed in a significant way around the world and particularly in France. The most economically important bivalve species is the Pacific oyster, Crassostrea gigas. This species is frequently reared in disturbed ecosystems subject to pollutants which affect the environmental quality of coastal waters.

Among environmental pollutants, heavy metals may have major ecological consequences. Some of the pollutants introduced in land and aquatic ecosystems may possess an important toxic potential (1). Metals are not degradable and may thus persist for long periods in ecosystems. Moreover, physical, chemical and biological process have a greater tendency to concentrate than to dilute heavy metals (2). In this way, aquatic animals including marine bivalves are likely to be exposed to elevated concentrations of pollutants. Oysters and other bivalve molluscs have been postulated as ideal indicator organisms for the assessment of environmental pollution $(3,4)$. They are already used in different programs monitoring pollution in estuarine ecosystems. Through their ubiquitous, benthic and sedentary mode of life, they are exposed to environmental modifications (temperature, salinity, pollutants, etc.) with no escaping possibility $(5,6)$. Their suspensivore mode of nutrition allows them to concentrate xenobiotics within their tissues by filtration of large volumes of seawater (7). Pollutant bioconcentration varies according to each pollutant and animal species but it may reach considerable levels. The reactions of animals faced with pollutants depend on the particular type of pollutant, nevertheless bioaccumulation constitutes a common response. Such a bioaccumulation mat be the consequence either of a direct contamination by water or an indirect contamination by food (8).

Although numerous studies have been made concerning the accumulation and toxic effects of heavy metals in bivalve molluscs, little effort has been directed at determining their toxic effects at a cellular level (9). Molluscs possess an open circulatory system which is continually exposed to the fluctuations of environmental factors including contaminants (10). The cellular defence system of bivalves comprises haemocytes which have various activities including phagocytosis, intracellular degradation of pathogens by means of hydrolytic enzymes, production of reactive oxygen metabolites and phenoloxidase activity $(11,12,13)$. The effects of environmental contaminants may correspond to a direct toxic action on tissues or cells or to more subtle alterations in homeostatic mechanisms including the immune system $(14,15)$.

Most studies on immunotoxicity consist in the collection of animals located on polluted sites and the determination of immune activity variations during a long period of time (16, 
17, 18, 19, 20, 21). However, in the present work, in vitro effects of different compounds in direct contact with Crassostrea gigas haemocytes were investigated. This approach may confirm results obtained from previous in vivo or in situ experiments. Moreover, this approach is suitable for developing immunotoxicity models in order to determine the mode of action of a particular pollutant. The actual aim of the present study was to work in acute toxicity conditions in order to obtain a rapid effect of heavy metals on immune cellular and plasmatic activities. Two heavy metals were selected (mercury and cadmium) and tested at different concentrations. Two forms of mercury were used : mercury chloride, which is the form rejected by industries, and methylmercury, potentially more toxic. The presence of these pollutants was reported in different shellfish culture areas at episodic high concentrations (22). Effects on haemocytes were studied using flow cytometry. Flow cytometry allows rapid analyses of the morphological and functional characteristics of free cell suspensions (23). Resulting data were based on autofluorescence light scattering parameters related to cell size and complexity (granularity). Cellular functions were also investigated using fluorescent markers : cell viability, presence of hydrolytic enzymes, and phagocytic activity. Phenoloxidase-like activity was also studied in the plasma fraction of haemolymph by spectrophotometry. 


\section{MATERIAL AND METHODS}

\section{Animals}

Pacific oysters, Crassostrea gigas, 8-10 cm in shell length were purchased from a shellfish farm located in Marenne-Oleron Bay (La Tremblade, Charente-Maritime, France) from February 2001 to April 2002. Two year-old animals originated from the same resource and were immediately processed after their arrival in the laboratory.

\section{Circulating haemocyte collection}

After opening oyster shell by cutting off the adductor muscle, haemolymph was withdrawn from the pericardial cavity using a 1-mL syringe equipped with a needle $(0,9525 \mathrm{~mm})$. For each oyster, 0.5-1 mL of haemolymph was collected. Haemolymph samples were conserved on ice to prevent haemocyte aggregation (24). Haemolymph samples were pooled to reduce interindividual variation and to provide enough haemocytes in order to fulfil requirements of pollutant exposure assays.

\section{Xenobiotics and exposure protocols}

Experiments consisted of an in vitro contact between haemocytes and selected pollutants. Analysis was carried out after different times of contact with the pollutant (4 or $24 \mathrm{~h}$ ). Incubations were realised in the dark at $20^{\circ} \mathrm{C}$. Three pollutants were tested : cadmium chloride ( $\mathrm{CdCl}_{2}$ anhydre, Sigma), mercury chloride (Mercure (II) chloride ( $\left.\mathrm{HgCl}_{2}\right)$, Rhône Poulenc), and methylmercury $\left(\mathrm{CH}_{3} \mathrm{HgCl}\right.$, Sigma).

\section{$\underline{\text { Cadmium chloride }}$}

Eight concentrations were tested: $3.10^{-11}, 3.10^{-10}, 3.10^{-9}, 3.10^{-8}, 3.10^{-7}, 3.10^{-6}, 3.10^{-5}$ and $3.10^{-4} \mathrm{M}$. Solutions were prepared in distilled water. Pollutant was added at $10 \mu \mathrm{L}$ per milliliter of haemolymph in order to limit osmolarity modification.

Twenty oysters were punctured and haemolymph samples were filtered on a $70 \mu \mathrm{m}$ mesh to eliminate debris. The haemolymph was then centrifuged ( $\left.260 \mathrm{~g}, 15 \mathrm{~min}, 10^{\circ} \mathrm{C}\right)$ and cellular pellets were resuspended in $5 \mathrm{~mL}$ of filtered seawater (FSW) added with antibiotics (kanamycin, erythromycin and oxolinic acid, $0.1 \mathrm{mg} \cdot \mathrm{mL}^{-1}$ ). Cellular concentrations were adjusted to $10^{6}$ cells. $\mathrm{mL}^{-1}$.

Haemocytes were incubated at $20^{\circ} \mathrm{C}$ for 4 and $24 \mathrm{~h}$. Mortality of haemocytes was evaluated. These experiments were carried out twice. 


\section{Mercury}

\section{Methylmercury}

Eight concentrations were tested: $2.10^{-11}, 2.10^{-10}, 4.10^{-10}, 2.10^{-9}, 2.10^{-8}, 2.10^{-7}, 4.10^{-7}$ and $2.10^{-6} \mathrm{M}$. Initial solution was prepared in $14 \mathrm{~N}$ nitric acid $\left(\mathrm{HNO}_{3}\right)$ and further dilutions were prepared in distilled water. Pollutant was added at $10 \mu \mathrm{L} . \mathrm{mL}^{-1}$ haemolymph.

Exposure protocol was similar to cadmium chloride protocol. Haemocytes were incubated at $20^{\circ} \mathrm{C}$ for 4 and $24 \mathrm{~h}$. Haemocyte mortality was evaluated. Experiments were carried out twice.

\section{Mercury chloride}

Two series of experiments were carried out using $\mathrm{HgCl}_{2}$ :

1- 4 concentrations were tested: $2.10^{-7}, 2.10^{-6}, 2.10^{-5}$ and $2.10^{-4} \mathrm{M}$. Initial solution was prepared in $0.3 \mathrm{~N}$ nitric acid $\left(\mathrm{HNO}_{3}\right)$ and further dilutions were prepared in distilled water. The pollutant was added at $1 \mu \mathrm{L} \cdot \mathrm{mL}^{-1}$ haemolymph. Exposure protocol was similar to cadmium chloride protocol.

Haemocytes were submitted at 4 treatments : (i) centrifugation with resuspending in FSW; (ii) centrifugation with resuspending in FSW supplied with antibiotics (flumequin 30 mg.mL ${ }^{-1}$, penicillin $0.75 \mathrm{mg} \cdot \mathrm{mL}^{-1}$, streptomycin $1.5 \mathrm{mg} \cdot \mathrm{mL}^{-1}$, and kanamycin, oxolinic acid, and erythromycin $0.1 \mathrm{mg} \cdot \mathrm{mL}^{-1}$ ) ; (iii) no centrifugation and addition of the same antibiotics ; (iiii) no centrifugation and no antibiotics.

Haemocytes were incubated at $20^{\circ} \mathrm{C}$ for 4 and $24 \mathrm{~h}$. Haemocyte mortality was evaluated. Experiments were carried out three times.

2- 3 concentrations were tested: $2.10^{-6}, 2.10^{-5}$ and $2.10^{-4} \mathrm{M}$. All solutions were prepared in $0.3 \mathrm{~N}$ nitric acid $\left(\mathrm{HNO}_{3}\right)$ to preserve their activity (25). Twenty oysters were punctured and haemolymph samples were pooled. The pollutant was added at $10 \mu \mathrm{L} . \mathrm{mL}^{-1}$ haemolymph. Haemocytes were incubated 4 and $24 \mathrm{~h}$ at $20^{\circ} \mathrm{C}$. Haemocyte parameters were evaluated (enzymatic activities, phagocytosis, mortality). Experiments were repeated three times.

\section{Cell analysis by flow cytometry}

Haemocyte analysis using flow cytometry (EPICS XL 4, Beckman Coulter) was previously described (26). For each haemocyte sample, 10000 events were counted. Results were expressed as cell cytograms indicating the size (FSC value), the complexity (SSC value) and the fluorescence channel(s) corresponding to the marker used. Recorded fluorescence 
depended on the monitored parameters : enzymes and phagocytosis were measured using FL1 and mortality using FL3.

Mortality was quantified using $200 \mu \mathrm{L}$ of haemolymph. Haemocytes were incubated in the dark for $30 \mathrm{~min}$ at $4{ }^{\circ} \mathrm{C}$ with $10 \mu \mathrm{L}$ of propidium iodide (PI, $1.0 \mathrm{mg} \cdot \mathrm{mL}^{-1}$, Interchim).

Esterase, aminopeptidase and peroxidase activities were evaluated with commercial kits (Cell Probe ${ }^{\mathrm{TM}}$ Reagents, Beckman Coulter). Each analysis required $200 \mu \mathrm{L}$ of haemolymph and $20 \mu \mathrm{L}$ of the corresponding kit (FDA•Esterase, A•Aminopeptidase $\mathrm{M}$ and DFCH, PMA•Oxidative Burst). Haemocytes were incubated in the dark at ambient temperature for $15 \mathrm{~min}$ for esterases and peroxidases and for $30 \mathrm{~min}$ for aminopeptidases. PMA-peroxidase activity was specifically inhibited using sodium azide $\left(\mathrm{NaN}_{3}\right.$, Sigma) at different concentrations : $3.10^{-7}, 3.10^{-6}, 3.10^{-5}, 3.10^{-4}, 10^{-3}, 10^{-2}, 2.10^{-2}, 3.10^{-2}, 6.10^{-2} \mathrm{M}$. Aminopeptidase activity was inhibited using bestatin (Sigma) at two concentrations : $5.10^{-4}$ and $5.10^{-3} \mathrm{M}$.

Phagocytosis was measured by ingestion of fluorescent beads. Five hundred $\mu \mathrm{L}$ of haemolymph were incubated for $1 \mathrm{~h}$ in the dark at ambient temperature with $10 \mu \mathrm{L}$ of a 1/10 dilution of Fluorospheres ${ }^{\circledR}$ carboxylate-modified microspheres (diameter $1 \mu \mathrm{m}$, Interchim). Phagocytosis was controlled using epifluorescence microscopy (27) (data not shown).

\section{Phenoloxidase-like (PO-like) activity detection}

Haemolymph samples were centrifuged $\left(260 \mathrm{~g}, 10 \mathrm{~min}, 4^{\circ} \mathrm{C}\right)$. The acellular fraction (supernatant) was frozen at $-20^{\circ} \mathrm{C}$ for further analysis. Detection of PO-like activity in acellular fraction samples was carried out by measurement of L-Dopa transformation in dopachromes. Transformation was monitored by spectrophotometry at $490 \mathrm{~nm}$. Samples were distributed in 96 well microplates. Purified trypsin TPCK (N-Tosyl-l-phenylalanine chloromethyl ketone, 1g. $\mathrm{L}^{-1}$, Sigma) was tested as an activator of PO activity. Phenylthiourea PTU (1-Phenyl-3-(2-Thiazolyl)-2-Thiourea, $10 \mathrm{mM}$, Sigma), a specific inhibitor of PO activity, was also tested. Sixty $\mu \mathrm{L}$ of cacodylate buffer (CAC), $20 \mu \mathrm{L}$ of a PO activity modulator, $20 \mu \mathrm{L}$ of L-Dopa (L-3,4-dihydroxyphénylalanine, $3 \mathrm{mg} . \mathrm{mL}^{-1}$, Sigma) and $20 \mu \mathrm{L}$ of sample were added in each well. PO-like activity detection in presence of mercury was carried out. Mercury $\left(\mathrm{HgCl}_{2}\right)$ was used at $2.10^{-6}$ and $2.10^{-5} \mathrm{M}$ and $1 \mu \mathrm{L}$ was added in presence of TPCK. 


\section{Statistical analysis}

For each pollutant, cellular parameters were analysed three times after 4 and $24 \mathrm{~h}$ incubations. Results were analysed using a non-parametric Kruskall-Wallis test for independent samples. $\mathrm{H}_{0}$ was rejected when $p \leq 0.05$. In the case of the reject of $\mathrm{H}_{0}$, an $a$ posteriori Student-Newman-Keuls (SNK) test was used. 


\section{RESULTS}

\section{Pollutant effects on haemocyte mortality}

Incubations with increasing concentrations of cadmium chloride were conducted on haemocytes. Results after 4 and $24 \mathrm{~h}$ of incubation at $20^{\circ} \mathrm{C}$ are reported in Table 1 . Results showed no significant effect of cadmium after $4 \mathrm{~h}$ and $24 \mathrm{~h}$.

In presence of methylmercury, haemocyte mortalities ranged from $18 \%\left(2.10^{-10} \mathrm{M}\right)$ to $31 \%$ $\left(2.10^{-6} \mathrm{M}\right)$ at $24 \mathrm{~h}$ (Figure 1a). However, these differences were not statistically significant. With mercury chloride, a dose-dependent increase of mortality was reported after 4 and 24 h of contact : haemocytes presented $50 \%$ and $80 \%$ of mortality at 4 and 24 h respectively at $2.10^{-4} \mathrm{M}$ (Figure $1 \mathrm{~b}$ ).

\section{Pollutant effects on haemocyte cellular activities}

Esterase, peroxidase, aminopeptidase and phagocytosis activities were evaluated after 4 and $24 \mathrm{~h}$ of contact with increasing concentrations of mercury chloride. Mercury presented a significant effect on percentages of aminopeptidase (AP) positive cells after $24 \mathrm{~h}$ incubation. Percentages of haemocytes presenting an AP activity were important (75-90\%) after $4 \mathrm{~h}$ incubation for all concentrations tested (Figure 2a). Although no AP activity was detected in control haemocytes after $24 \mathrm{~h}$ incubation $(<5 \%)$, percentages of AP positive cells remained important (79\%) in presence of mercury (Figure 2b). The effect of mercury chloride was dose-dependent and statistically significant. However mercury had no significant effect on esterase, peroxidase and phagocytosis activities (Figures 2a, 2b).

Experiments were also conducted on haemocyte in presence of enzyme inhibitors (sodium azide and bestatin) in the absence of pollutant in order to control labelling specificity. Addition of sodium azide demonstrated a dose dependent reduction of peroxidase activity (Figure 3a). Addition of bestatin showed a dose-dependent decrease of aminopeptidase activity (Figure 3b).

\section{Pollutant effects on PO-like activity}

The effect of mercury was also tested on plasmatic PO-like activity. The optical density was different in controls ( $\mathrm{OD}=0.6)$ and in acellular fraction incubated in presence of mercury $(\mathrm{OD}=0.03)$ after $21 \mathrm{~h}$ incubation (Figure 4). PO-like activity decreased after $3 \mathrm{~h}$ incubation for both mercury concentrations tested. Statistical analysis confirmed the effect of mercury on PO-like activity detection. 
Interactions between media and mercury on haemocyte mortality

Experiments including different maintenance conditions of haemocytes in presence of mercury chloride were conducted. After $4 \mathrm{~h}$ of incubation at $20^{\circ} \mathrm{C}$ (Figure $5 \mathrm{a}$ ), mercury induced a statistically significant and dose-dependent increasing mortality of haemocytes maintained in haemolymph with or without antibiotics. Cells maintained in FSW presented the highest mortality ( $50 \%$ for $2.10^{-4} \mathrm{M}$ ), but not in a dose dependent way. Results after 24 $\mathrm{h}$ of contact with mercury chloride at $20^{\circ} \mathrm{C}$ showed increasing of mortality but not in a dose-dependent way if the highest concentration of mercury $\left(2.10^{-4} \mathrm{M}\right)$ was included (Figure 5b). For cells incubated without antibiotics, mortality of the control was elevated (20\% in FSW and 36\% in haemolymph). 


\section{DISCUSSION}

Inhibition of enzymatic activities detected by flow cytometry

Experiments involving enzyme inhibitors were carried out in order to control the specificity of haemocyte labelling, since the kits used were first developed for mammal cells. Addition of sodium azide demonstrated a significant decrease of peroxidase activity in oyster haemocytes. Sodium azide is known to be a strong inhibitor of oxidative burst which involves peroxidase and particularly myeloperoxidase (28, 29, 30, 31). Addition of bestatin resulted in a dose-dependent inhibition of the haemocyte labelling. Bestatin is known as a specific inhibitor of aminopeptidase activity in mammals (32, 33, 34). These results indicate that the commercial kits may be used to detect specifically enzymes in oyster haemocytes.

The observation of haemocytes by epifluorescence microscopy assessed the validity of flow cytometry. After $1 \mathrm{~h}$ of incubation with beads, haemocytes presented ingested fluorescent beads, using an epifluorescent microscope as previously described in Ostrea edulis (35).

\section{Polluant effects on haemocytes}

Haemocytes are known for their properties of spontaneous aggregation. This phenomenon appears during cell collection and must be integrated in cell analysis. No anti-aggregant solution was used during haemocyte collection because such solutions may inhibit haemocyte activities. Alsever solution, an anti-aggregant solution, decreases oxygen metabolite production in Mytilus galloprovincialis Lk (36). Moreover, aggregation of Crassostrea gigas haemocytes is strongly reduced at $4^{\circ} \mathrm{C}(24)$. Another study indicates that the maintenance of haemocytes on ice prevents their aggregation (37).

The volumes of pollutants finally added were selected so as not to modify osmolarity (10 $\mu \mathrm{L} . \mathrm{mL}^{-1}$ of haemolymph). First solutions of pollutants were prepared at high concentrations in order to obtain high final dilution factors of the solvent (between 100 and 10000 for the different pollutants). High pollutant concentrations were used in order to investigate acute toxicity on oyster haemocytes. Indeed, no bivalve cell line is available and no culture system permits the maintenance of haemocytes in vitro for long periods after collection. Furthermore, since bivalves can accumulate contaminants in their tissues, the concentrations used on cells are likely to can be similar to those existing in animals $(25,38,39,40,41,42,43)$. 
Cadmium induced no effect on haemocyte mortality. Literature reports contrasting observations : after $24 \mathrm{~h}$ of exposition with $10^{-5}$ to $2.10^{-3} \mathrm{M}$ of $\mathrm{CdCl}_{2}$, haemocytes of Mytilus galloprovincialis presented a dose-dependent increase of mortality (44). Another study showed influence of Cd on Mya arenaria haemocytes for $10^{-4}$ and $10^{-3} \mathrm{M}$ (1). However, these concentrations are higher than those used in the present study. At lowest concentrations, Cd was found to be not immunotoxic since it did not inhibit phagocytosis activity of Tapes philippinarum haemocytes (45). In the present study, cadmium was not able to kill haemocytes from C. gigas at concentrations ranging from $3.10^{-11}$ to $3.10^{-4} \mathrm{M}$. This pollutant did not demonstrate an immunotoxic potential by killing haemocytes.

Mercury is known for its high toxicity and its bioaccumulation in various organisms which is a significant cause of mortality of aquatic species (38). Methylmercury is supposed to be the most toxic form of mercury : the methyl group facilitate penetration into cells and binding to proteins. The present study reports no significant variation of mortality of haemocytes. Literature reports increasing of mortality on haemocytes of $M$. edulis and Mactromeris polynyma for $10^{-4} \mathrm{M}$ and an earlier effect on phagocytosis $\left(10^{-7} \mathrm{M}\right)(1,46)$. These concentrations are higher than those reported here. In our experimental conditions, methylmercury was not immunotoxic for haemocytes, like cadmium.

Mercury chloride is reported to be less toxic than methylmercury. The employed concentrations in this study were thus higher. Increasing concentrations $\left(2.10^{-6}, 2.10^{-5}\right.$ and $2.10^{-4} \mathrm{M}$ ) caused oyster haemocyte mortality after $4 \mathrm{~h}$ incubation. Such a rapid effect was previously reported in Eastern oyster, C. virginica, haemocytes (9). Haemocyte mortality increased in a dose-dependent way after $2 \mathrm{~h}$ of contact with $2.10^{-6}, 4.10^{-6}$ and $2.10^{-5} \mathrm{M}$ of $\mathrm{HgCl}_{2}$ (9). In vitro studies showed an effect of mercury at higher concentrations than those used in this study : increasing mortality was detected on haemocytes of Mya arenaria L., Mya truncata, M. edulis and Mactromeris polynyma at $10^{-3} \mathrm{M}$ and higher concentrations $(1,46)$.

Some cellular activities were investigated in the presence of mercury chloride. An effect of mercury on percentages of AP positive cells was noticed : after $24 \mathrm{~h}$ of incubation, the percentage of AP positive cells increased following increasing mercury concentrations. Two hypothesis can be formulated to explain this result: (i) mercury acts indirectly on haemocytes by limiting bacterial development in the medium $(47,48)$, thus preserving cell 
activities; or (ii) conservation of AP positive cells is a real cellular reaction induced by mercury. Aminopeptidases are hydrolytic enzymes already described in the haemolymph of Biomphalaria glabrata and Crassostrea virginica (49). Some of them are present in granules of granulocytes, are released into serum by degranulation (50) and act in postphagocytosis reactions (51). These enzymes degrade surface proteins of parasites (50). The AP activity is also well known in vertebrates : they play a key role in the generation of MHC presented peptides (52, 53).

Mercury may cause a modulation of some haemocyte activities following its concentration. It has been proved to modify cellular activity, particularly phagocytosis. A previous in vitro study (9) reported an increasing effect of mercury on phagocytosis at $4.10^{-7} \mathrm{M}$, and a dose-dependent decrease for $2.10^{-6}, 4.10^{-6}$ and $2.10^{-5} \mathrm{M}$. Mercury also caused a decrease of phagocytosis for $10^{-6} \mathrm{M}$ on haemocytes of Mya arenaria L., Mya truncata, M. edulis and Mactromeris polynyma $(1,46)$. The present work did not report effects of mercury neither on phagocytosis, nor on esterase and peroxidase activities. These three parameters are known to be related since phagocytosis is accompanied by the release of a variety of cytotoxic agents (reactive oxygen species and peroxidases which are involved in the oxidative burst) and lysosomal enzymes including esterases (54, 55, 56, 57).

Concerning phenoloxidase (PO)-like activity, mercury completely inhibited the transformation of L-Dopa in haemolymph. The maximum PO-like activity was detected after $21 \mathrm{~h}$ incubation in oysters, which suggests the presence of an inactive form of PO-like enzyme as it was already demonstrated in Mytilus edulis (58). Effect of pollutants on POlike activity was studied with copper which is known to reduce this activity in Mytilus edulis L. (59). Polychlorinated biphenyls decreased PO-like activity in gray shrimp (Crangon crangon L.) after a five day exposure (60). On the contrary, PO-like activity was found to increase in presence of fluoranthene in Mytilus edulis (61). Response may change regarding the pollutant. In this work, mercury acts rapidly on PO-like activity. Its effect is dose-dependent and time-dependent.

\section{Interactions between media and mercury on haemocyte mortality}

The use of different incubation conditions of cells confirms that cell centrifugation may be a factor of stress and decreased cell viability as compared with cells incubated in 
haemolymph. For this reason, the effects of mercury are detectable at lower concentrations in FSW : cells may indeed be more sensitive to a pollutant when they are stressed.

The condition leading to the lowest mortality without pollutant seems to be haemolymph supplied with antibiotics. Antibiotic supplementation may reduce bacterial development, whereas haemolymph certainly furnishes active molecules involved in cell survival. RPMI, $\mathrm{NaCl}$ supplied RPMI, and haemolymph have been tested in a previous study (46) ; haemolymph appeared to be the only medium in which cells conserved phagocytosis activity. These results allowed to define haemolymph supplied with antibiotics as a medium of interest for in vitro toxicity studies.

Cadmium appears as a non-immunotoxic substance for oyster haemocytes. On the contrary, mercury is an active pollutant. It causes cell death and haemocyte activity modulation. Results were confirmed by experiments undertaken by flow cytometry and by spectrophotometry. Mercury seems to be a molecule of interest for the study of in vitro immunotoxicity. It causes effects in a short period of time. In vitro experiments may be used as a tool to determine mechanisms of pollutant immunotoxicity. This approach may help to understand some responses showed by in vivo and in situ studies and to confirm the hazardous potential of certain molecules as compared to others. However, in our experiment, pollutants were added separately to haemocytes, whereas animals in natural environments are submitted to mixed pollutants. It would thus be interesting to conduct in vitro experiments using mixed heavy metals. Antagonist or additive effects may exist: for instance, the presence of zinc or cadmium may decrease the toxic effects of mercury in vivo $(62,63)$.

High concentrations of mercury caused cell death, but little effect on other haemocyte parameters. This result can be related to the analysis method since parameters were only measured on surviving cells. It may be hypothesised that mercury has a direct action by inducing cell death. Such a mode of action would result in a decrease of haemocyte number, and thus a reduction of the capacity of defence. PO-like activity decreases also in presence of mercury. Reports have been made on the possible existence of a relationship between pollutants and diseases. Indeed, chronic exposure of Crassostrea virginica to TBT increased progression of Perkinsus marinus infection (64). Thus, we may suspect that in areas contaminated with mercury, oyster defence capacities may be reduced, which could enhance the sensitivity of animals to infectious diseases. 


\section{Acknowledgments}

P. Goulletquer is acknowledged for allowing the work at the IFREMER station in La Tremblade (Charente-Maritime, France). This research was supported in part by the Regional Shellfish Farming Section. Thanks to Valerie Barbosa Solomieu for her reading of this document. Drs Eric Thiebaut (Université de Paris VI) and Patrick Soletchnick (LCPC, IFREMER La Tremblade) are thanked for their help in statistical treatment. 


\section{REFERENCES}

1 Brousseau, P., Pellerin, J., Morin, Y., Cyr, D., Blakley, B., Boermans, H., and Fournier, M. (2000). Flow cytometry as a tool to monitor the disturbance of phagocytosis in the clam Mya arenaria haemocytes following in vitro exposure to heavy metals. Toxicology 142, 145-156.

2 Frazier, J.M. (1979). Bioaccumulation of cadmium in marine organisms. Environment Health Perspectives 28, 75-79.

3 Cossa, D. (1985). Le cadmium et le mercure en milieu côtier : biogéochimie et utilisation du genre Mytilus comme indicateur quantitatif. Thèse de doctorat d'état ès Sciences Naturelles, 387 pp.

4 Lopez-Barea, J., and Pueyo, C. (1998). Mutagen content and metabolic activation of promutagens by molluscs as biomarkers of marine pollution. Mutation Resarch 399, 315.

5 Oubella, R., \& Auffret, M. (1995). Immuno-modulation in populations of mollusc bivalves from the Rade de Brest. Acte de Rencontre Scientifique Internationale (Programme Rade de Brest) 1, 307-319.

6 Wade, T.L., Sericano, J.L., Gardinali, P.R., Wolff, G., \& Chambers, L. (1998). NOAA's « Mussel Watch» project: current use organic compounds in Bivalves. Marine Pollution Bulletin 37 (1-2), 20-26.

7 Domart-Coulon, J., Auzoux-Bordenave, S., Doumnec, D., \& Khalanski, M. (2000). Cytotoxicity assessment of antibiofouling compounds and by-products in marine bivalve cell culture. Toxicology in vitro 14, 245-251.

8 Amiard-Triquet, C. (1989). Bioaccumulation et nocivité relatives de quelques polluants métalliques à l'égard des espèces marines. Bulletin d'Ecologie 20 (2), 129-151.

9 Cheng, T.C., \& Sullivan, J.T. (1984). Effects of heavy metals on phagocytosis by molluscan haemocytes. Marine Environmental Research 14, 305-315.

10 Cheng, T.C. (1981). Bivalves. In Invertebrate Blood Cells (N.A. Ratcliffe, A.F. Rowley, eds), pp. 233-299. Academic Press, London.

11 Cheng, T.C., \& Rodrick, G.E. (1975). Lysosomal and other enzymes in the haemolymph of Crassostrea virginica, and Mercenaria mercenaria. Comparative Biochemistry and Physiology Part B 52, 443-447.

12 Cheng, T.C. (1988). In vivo effects of heavy metals on cellular defence mechanisms of Crassostrea virginica: total and differential cell counts. Journal of Invertebrate Pathology 51, 207-214. 
13 Pipe, R.K. (1992). Generation of reactive oxygen metabolites by the haemocytes of the mussel Mytilus edulis. Developmental Comparative Immunology 16, 111-122.C

14 Cajaraville, M.P., Olabarrieta, I., \& Marigomez, I. (1996). In vitro activities in mussel haemocytes as biomarkers of environmental quality : a case study in the Abra estuary (Biscay Bay). Ecotoxicology and. Environmental Safety 35, 253-260.

15 Coles, J.A., \& Pipe, R.K. (1994). Phenoloxidase activity in the haemolymph and haemocytes of the marine mussel Mytilus edulis. Fish and Shellfish Immunology 4, 337-352.

16 Sami, S., Faisal, M., and Huggett, R.J. (1992). Alterations in cytometric characteristic of haemocytes from the American oyster Crassostrea virginica exposed to a polycyclic aromatic hydrocarbon (PAH) contaminated environment. Marine Biology 113, 247252.

17 Pipe, R.K., Coles, J.A., Thomas, M.E., Fossato, V.U., and Pulsford, A.L. (1995). Evidence for environmentally derived immunomodulation in mussels from the Venice lagoon. Aquatic Toxicology 32, 59-73.

18 Fisher, W.S., Oliver, L.M., Winstead, J.T., and Long, E.R. (2000). A survey of oysters Crassostrea virginica from Tampa Bay, Florida : associations of internal defence measurements with contaminant burdens. Aquatic Toxicology 51, 115-138.

19 Lowe, D.M., and Fossato, V.U. (2000). The influence of environmental contaminants on lysosomal activity in the digestive cells of mussels (Mytilus galloprovincialis) from the Venice Lagoon. Aquatic Toxicology 48 (2-3), 75-85.O

20 Olivier, L.M., Fisher, W.S., Winstead, J.T., Hemmer, B.L., and Long, E.R. (2001). Relationships between tissue contaminants and defence-related characteristics of oysters (Crassostrea virginica) from five Florida bays. Aquatic Toxicology 55, 203222.

21 Chu, F-L., Volety, A.K., Hale, R.C., and Huang, Y. (2002). Cellular response and disease expression in oysters (Crassostrea virginica) exposed to suspended field contaminated sediments. Marine Environmental Research 53, 17-35.

22 Cossa, D., Thibaud Y., Romeo, M., and Gnassia-Barelli, M. (1990). Le mercure en milieu marin : biogéochimie et écotoxicologie. Rapport Scientifique et Technique de I'IFREMER 19, $130 \mathrm{pp}$.

23 Renault, T., Xue, Q.G., and Chilmonczyk, S. (2001). Flow cytometric analysis of European flat oyster, Ostrea edulis, haemocytes using a monoclonal antibody specific for granulocytes. Fish and Shellfish Immunology 11 (3), 269-274. 
24 Auffret, M., \& Oubella, R. (1997). Haemocyte aggregation in the oyster Crassostrea gigas: in vitro measurement and experimental modulation by xenobiotics. Comparative Biochemistry and Physiology Part A 118 (3), 705-712.

25 Radenac, G., Fichet, D., and Miramand, P. (2001). Bioaccumulation and toxicity of 4 dissolved metals in Paracentrotus lividus sea-urchin embryo. Marine Environmental Research 51, 151-166.

26 Gagnaire, B., Renault, T., Bouilly, K., Lapegue, S., and Thomas-Guyon, H. (2003). Study of atrazine effects on Pacific oyster, Crassostrea gigas, haemocytes. Current Pharmaceutical Design 9 (2), 193-199

27 Xue, Q. (1998). Caractérisation morphologique et fonctionnelle des hémocytes chez l'huître plate, Ostrea edulis. Thèse de $3^{\text {ème }}$ cycle, Université de Bretagne Occidentale (Brest). 323 pp.

28 Chagot, D. (1989). Caractérisation morphologique et fonctionnelle des hémocytes d'Ostrea edulis et de Crassostrea gigas, mollusques bivalves. Etude in vitro de leurs intéractions avec le protozoaire Bonamia ostreae (Ascetospora). Mémoire de Diplôme de l'Ecole Pratique des Hautes Etudes, 71 p.

29 Simms, H.H., D’Amico, R., and Burchard, K.W. (1990). Intra-abdominal sepsis : effects on polymorphonuclear leukocyte Fc receptor-mediated phagocytosis. Journal of Surgical Research 49 (1), 49-54.

30 Carballal, M.J., Lopez, C., Azevedo, C., and Villalba, A. (1997). Enzymes involved in defense functions of haemocytes of mussel Mytilus galloprovincialis. Journal of Invertebrate Pathology 70, 96-105.

31 Maselli, A., Laevsky, G., and Knecht, D.A. (2002). Kinetics of binding, uptake and degradation of live fluorescent (DsRed) bacteria by iyctyostelium discoideum. Microbiology 148 (2), 413-420.

32 Walker, B., Darkins, P.A., McKervey, M.A., Moncrieff, H.M., and Lynas, J.F. (2000). Potent new leucine aminopeptidase inhibitor of novel structure synthesised by a modifies wadsworth-emmons (Horner) wittig procedure. Bioorganics and Medicinal Chemistry Letters 10, 1481-1482.

33 Stamper, C., Bennett, B., Edwards, T., Holz, R.C., Ringe, D., and Petsko, G. (2001). Inhibition of the aminopeptidase from Aeromonas proteolytica by LLeucinephosphonic acid. Spectroscopic and cristallographic characterization of the transition state of peptide hydrolysis. Biochemistry 40, 7035-7046. 
34 Chandra, D., Ramana, K.V., Wang, L., Christensen, B.N., Bhatnagar, A., and Srivastava, S.K. (2002). Inhibition of fiber cell globulization and hyperglycemiainduced lens opacification by aminopeptidase inhibitor bestatin. Investigative Ophtalmology and Visual Science 43 (7), 2285-2292.

35 Xue, Q.G., Renault, T., and Chilmonczyk, S., (2001). Flow cytometric assessment of haemocyte sub-populations in the European flat oyster, Ostrea edulis, haemolymph. Fish and Shellfish Immunology 11, 557-567.

36 Torreilles, J., Guérin, M.C., \& Roch, P. (1999). Modified Alsever’s solution is not a good medium for reactive oxygen metabolite study in bivalves. Fish and Shellfish Immunology 8, 65-69.

37 Anderson, R.S., Oliver, L.M., and Jacobs, D. (1992). Immunotoxicity of cadmium for the eastern oyster (Crassostrea virginica [Gmelin, 1791]) : effects on haemocyte chemiluminescence. Journal of Shellfish Research 11 (1), 31-35.

38 Cossa, D., \& Fichet, A. (1999). La dynamique du mercure. Programme scientifique Seine-Aval, $\mathrm{n}^{\circ} 11$.

39 Akcha, F., Burgeot, T., Venier, P., and Narbonne, J.F. (1999). Relationship between kinetics of benzo[a]pyrene bioaccumulation and DNA binding in the mussel Mytilus galloprovincialis. Bulletin of environmental Contamination and Toxicology 62, 455462.

40 Basak, S.B., Oneto, M.L., Verrengia-Guerrero, N.R., and Kesten, E.M. (1997). Accumulation and elimination of pentachlorophenol in the freshwater bivalve Corbicula fulminea. Bulletin of Environmental Contamination and Toxicology 58, 497503.

41 Chan, H.M., (1988). Accumulation and tolerance to cadmium, copper, lead and zinc by the green mussel Perna viridis. Marine Ecology Progress Series 48, 295-303.

42 Munoz, I., and Roses, N. (2000). Comparison of extraction methods for the determination of atrazine accumulation in freshwater molluscs (Physa acuta Drap. and Ancylus fluviatis Müll., Gastropoda). Water Research 34 (10), 2846-2848.

43 Simkiss, K., Taylor, M., and Mason, AZ. (1982). Metal detoxification and bioaccumulation in molluscs. Marine Biology Letters 3, 187-201.

44 Olabarrieta, I., L’Azou, B, Yuric, S., Cambar, J., and Cajaraville, M.P. (2001). In vitro effects of cadmium on two different animal cell models. Toxicology in vitro 15 (4-5), $511-517$ 
45 Matozzo, V., Ballarin, L., Pampanin, D.M., and Marin, M.G. (2001). Effects of copper and cadmium exposure on functional responses of haemocytes in the clam, Tapes philippinarum. Archives of Environmental Contamination and Toxicology 41 (2), 163170

46 Sauvé, S., Brousseau, P., Pellerin, J., Morin, Y., Senecal, L., Goudreau, P., and 4nier, M. (2002). Phagocytic activity of marine and freshwater bivalves : in vitro exposure of haemocytes to metals (Ag, Cd, Hg and Zn). Aquatic Toxicology 58 (3-4), 189-200.

47 Cheng, T.C., Lie, K.J., Heyneman, D., and Richard, C.S. (1978). Elevation of aminopeptidase activity in Biomphalaria glabrata (Mollusca) parasitized by Echinostoma lindoense (Trematoda). Journal of Invertebrate Pathology 31, 57-62.

48 Hyndiuk, R.A., Burd, E.M., and Hartz, A. (1990). Efficacy and safety of mercuric oxide in the treatment of bacterial blepharitis. Antimicrobial Agents and Chemotherapy 34 (4), 610-613.

49 Stratton, G.W., Huber, A.L., and Corke, C.T. (1979). Effect of mercuric ion on the growth, photosynthesis, and nitrogenase activity of Anabaena inaequalis. Applied and Environmental Microbiology 38 (3), 537-543.

50 Cheng, T.C. (1983). The role of lysosomes in molluscan inflammation. American Zoology 23, 129-144.

51 Yoshino, T.P., and Cheng, T.C. (1976). Experimentally induced elevation of aminopeptidase activity in hemolymph cells of the American oyster, Crassostrea virginica. Journal of Invertebrate Pathology 27 (3), 367-370.

52 Rock, K.L., York, I.A., Saric, T., and Goldberg, A.L. (2002). Protein degradation and the generation of MHC class I-presented peptides. Advances in Immunology 80, 1-70.

53 York, I.A., Chang, S.C., Saric, T., Keys, J.A., Favreau, J.M., Goldberg, A.L., and Rock, K.L. (2002). The ER aminopeptidase ERAP1 enhances or limits antigen presentation by trimming epitopes to 8-9 residues. Nature Immunology 3 (12), 11771184.

54 Pipe, R.K. (1990a). Hydrolytic enzymes associated with the granular haemocytes of the marine mussel Mytilus edulis. Histochemical Journal 22, 595-603.

55 Schlenck, D., Martinez, P.G., and Livingstone, D.R. (1991). Studies on myeloperoxidase activity in the common mussel, Mytilus edulis. Comparative Biochemistry and Physiology Part C 99 (1/2), 63-68.

56 Pipe, R.K. (1992). Generation of reactive oxygen metabolites by the haemocytes of the mussel Mytilus edulis. Developmental and Comparative Immunology 16, 111-122. 
57 Torreilles, J., Guerin, M.C., and Roch, P. (1997). Peroxidase-release associated with phagocytosis in Mytilus galloprovincialis haemocytes. Developmental and Comparative Immunology 21 (3), 267-275.

58 Deaton, L.E., Jordan, P.J., \& Dankert, J.R. (1999). Phenoloxidase activity in the haemolymph of bivalve molluscs. Journal of Shellfish Research 18 (1), 223-226

59 Pipe, R.K., Coles, J.A., Carissan, F.M.M., \& Ramanathan, K. (1999). Copper induced immunomodulation in the marine mussel, Mytilus edulis. Aquatic Toxicology 46, 4354.

60 Smith,V.J., \& Johnston, P.A. (1992). Differential haemotoxic effect of PCB congeners in the common shrimp, Crangon crangon. Comparative Biochemistry and Physiology 101 (3), 641-649

61 Coles, J.A., Farley, S.R., and Pipe, R.K. (1994). Effects of fluoranthene on the immunocompetence of the common marine mussel, Mytilus edulis. Aquatic Toxicology 30, 367-379.

62 Gutierrez-Galindo, E.A., \& Breittmayer, J.P. (1981). Effet du zinc sur l'accumulation du mercure par la moule Mytilus edulis. Revue Internationale d'Océanographie Méd. Tomes LXIII-LXIV.

63 Breittmayer, J.P., Woaye, C., \& Zsurger, N. (1984). Effet du cadmium sur la fixation du mercure par la moule (Mytilus edulis). Journal de la Recherche Océanographique 9 (2), 66-68.

64 Anderson, R.S., Unger, M.A., \& Burreson, E.M. (1996). Enhancement of Perkinsus marinus disease progression in TBT-exposed oysters (Crassostrea virginica). Marine Environmental Research 42 (1-4), 177-180. 
Tableau 1 : Haemocyte mortality tested by flow cytometry with increasing concentrations of cadmium in vitro $\left(0-3.10^{-11}-3.10^{-10}-3.10^{-9}-3.10^{-8}-3.10^{-7}-3.10^{-6}-3.10^{-5}-3.10^{-4} \mathrm{M}\right)$ after 4 and $24 \mathrm{~h}$ incubation at $20^{\circ} \mathrm{C}$. Values are averages of two replicates.

\begin{tabular}{|c|c|c|c|c|c|c|c|c|c|}
\cline { 2 - 10 } \multicolumn{1}{c|}{} & Control & $3.10-11 \mathrm{M}$ & $3.10-10 \mathrm{M}$ & $3.10-9 \mathrm{M}$ & $3.10-8 \mathrm{M}$ & $3.10-7 \mathrm{M}$ & $3.10-6 \mathrm{M}$ & $3.10-5 \mathrm{M}$ & $3.10-4 \mathrm{M}$ \\
\hline $4 \mathrm{~h}$ & 9,3 & 9,4 & 9,0 & 10,7 & 9,7 & 9,2 & 9,6 & 10,5 & 10,7 \\
$24 \mathrm{~h}$ & 12,5 & 13,5 & 20,1 & 19,7 & 31,8 & 23,9 & 18,4 & 30,8 & 17,0 \\
\hline
\end{tabular}

Figure 1 : Haemocyte mortality tested by flow cytometry with increasing concentrations of mercury in vitro after 4 and $24 \mathrm{~h}$ incubation at $20^{\circ} \mathrm{C}$. Values are averages of three replicates

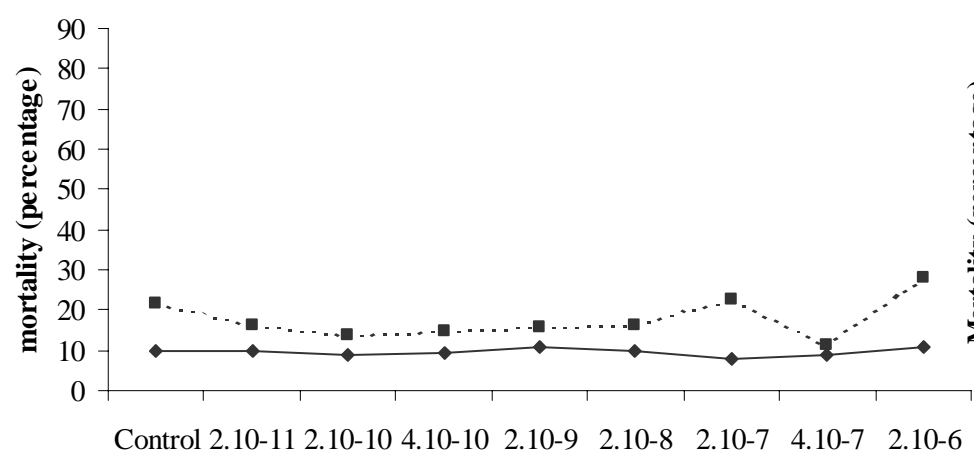

Concentration of methylmercury (M)

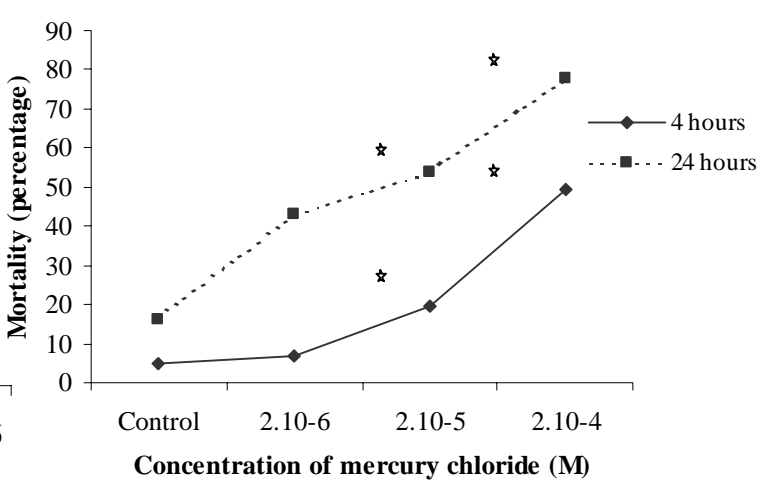

1.a : Contact with methylmercury (01.b : Contact with mercury chloride (0$2.10^{-11}-2.10^{-10}-4.10^{-10}-2.10^{-9}-2.10^{-8}-2.10^{-}$ $\left.2 \cdot 10^{-6}-2 \cdot 10^{-5}-2 \cdot 10^{-4} \mathrm{M}\right) . \quad \Pi=$ statistical $\left.{ }^{7}-4.10^{-7}-2.10^{-6} \mathrm{M}\right)$. difference for $p=0.05$. 
Figure 2 : Esterase, peroxidase, aminopeptidase and phagocytosis activity tested by flow cytometry with increasing concentrations of mercury chloride in vitro $\left(0-2.10^{-6}-2.10^{-5}-2.10^{-}\right.$ $\left.{ }^{4} \mathrm{M}\right)$ at $20^{\circ} \mathrm{C}$. Values are averages of three replicates.

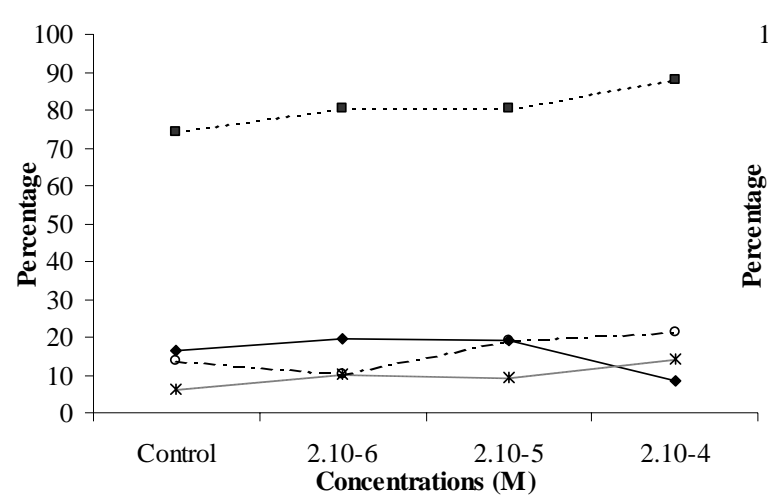

2.a : Results after $4 \mathrm{~h}$ of incubation.

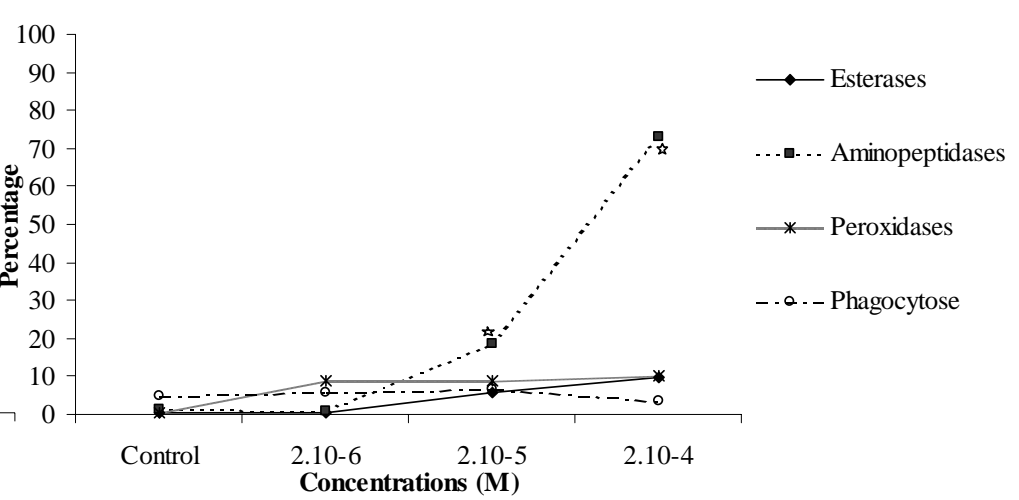

2.b : Results after $24 \mathrm{~h}$ of incubation. $\Pi=$ statistical difference for $p=0.05$. 
Figure 3 : Evaluation of enzymatic activities with specific inhibitors.

3.a : peroxidase positive cells percentage tested by flow cytometry with increasing concentrations of sodium azide in vitro $\left(0-3.10^{-7}-3.10^{-6}-3 \cdot 10^{-5}-3.10^{-4}-10^{-3}-10^{-2}-2 \cdot 10^{-2}-3.10^{-}\right.$ $\left.{ }^{2}-6.10^{-2} \mathrm{M}\right)$. Values are averages of three replicates.

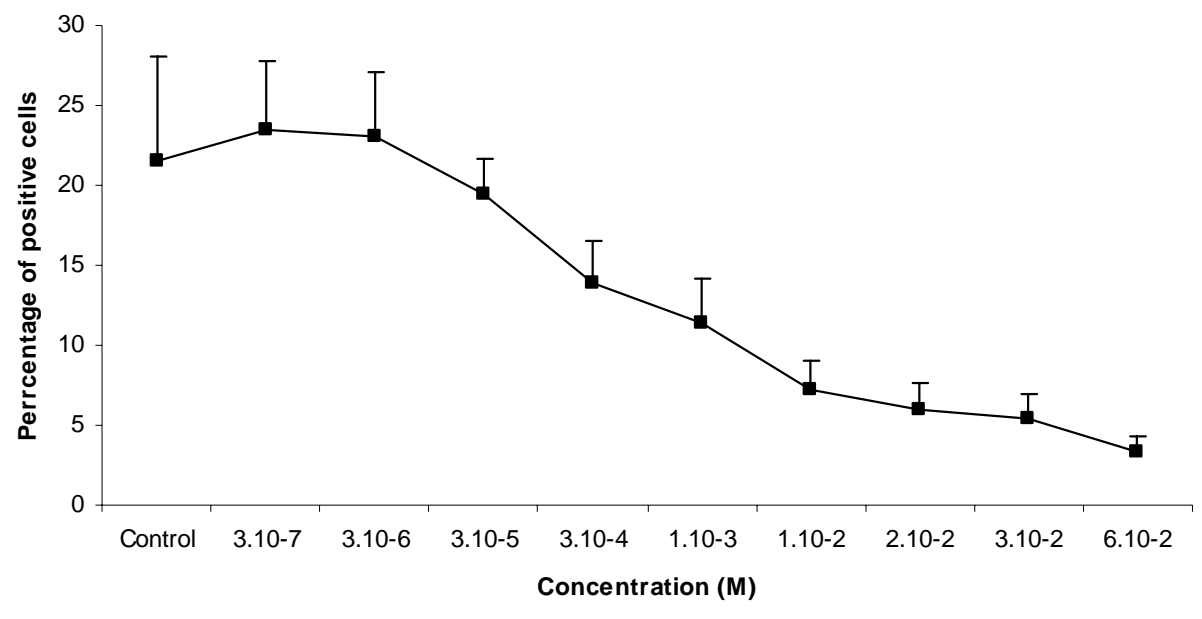

3.b : aminopeptidase positive cells percentage tested by flow cytometry with increasing concentrations of bestatin in vitro $\left(0-5 \cdot 10^{-2}-5 \cdot 10^{-1} \mathrm{M}\right)$. Values are averages of two replicates.

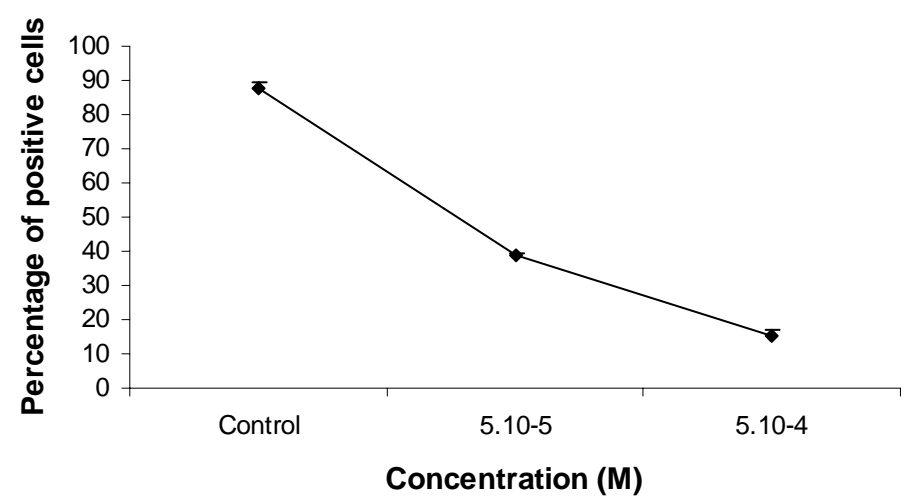


Figure 4 : PO-like activity tested by spectrophotometry with two concentrations of mercury chloride in vitro $\left(0-2 \cdot 10^{-6}-2 \cdot 10^{-5} \mathrm{M}\right)$ after $21 \mathrm{~h}$ incubation. Values are averages of two replicates.

$\Pi=$ statistical difference for $p=0.05$.

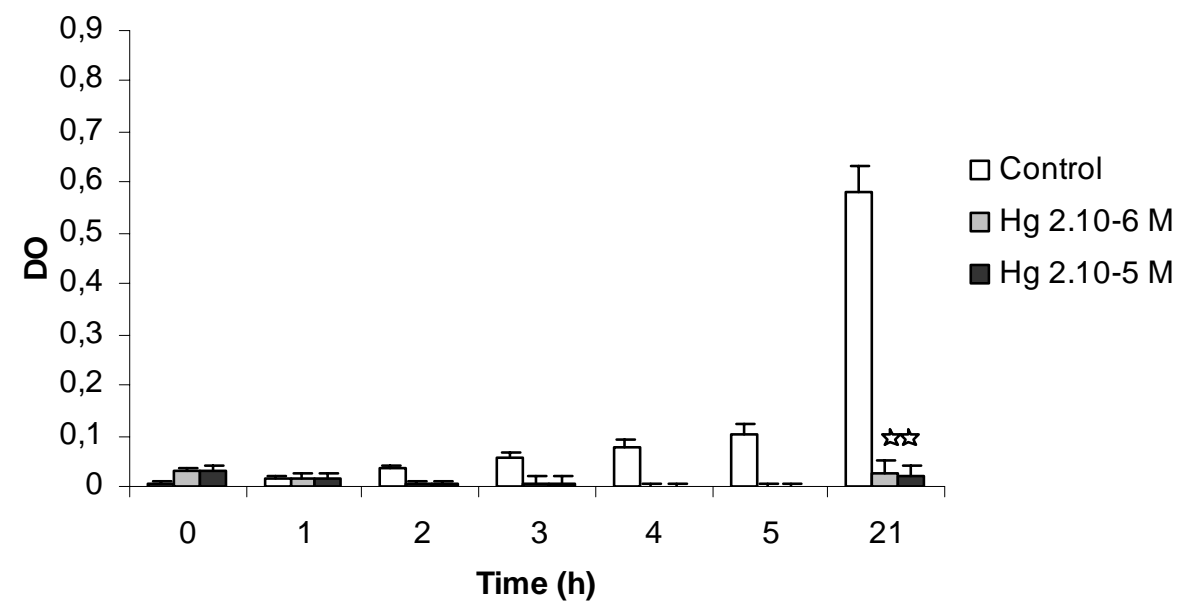

Figure 5 : Haemocyte mortality tested by flow cytometry with increasing concentrations of mercury chloride in vitro $\left(0-2 \cdot 10^{-7}-2 \cdot 10^{-6}-2 \cdot 10^{-5}-2 \cdot 10^{-4} \mathrm{M}\right)$ after incubation at $20^{\circ} \mathrm{C}$ with different treatments. Values are averages of three replicates.

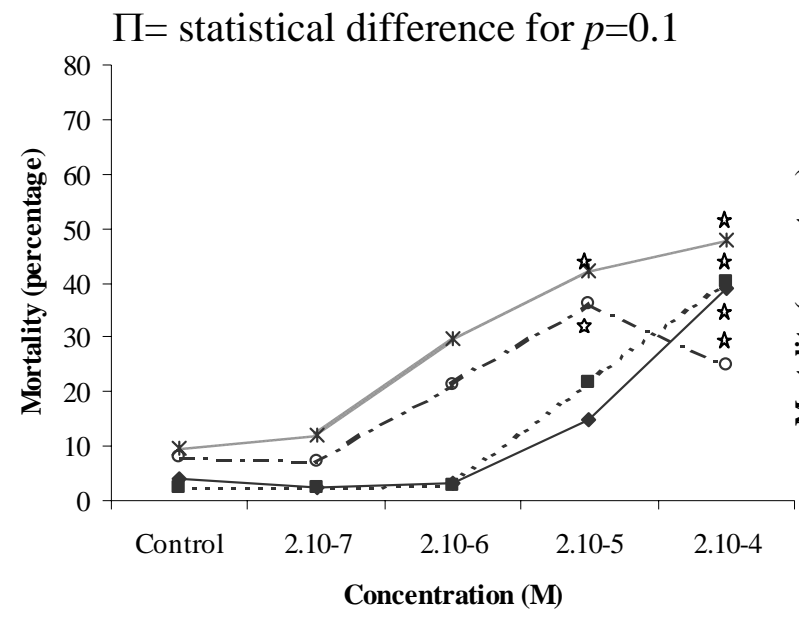

5.a : Results after $4 \mathrm{~h}$ of incubation.

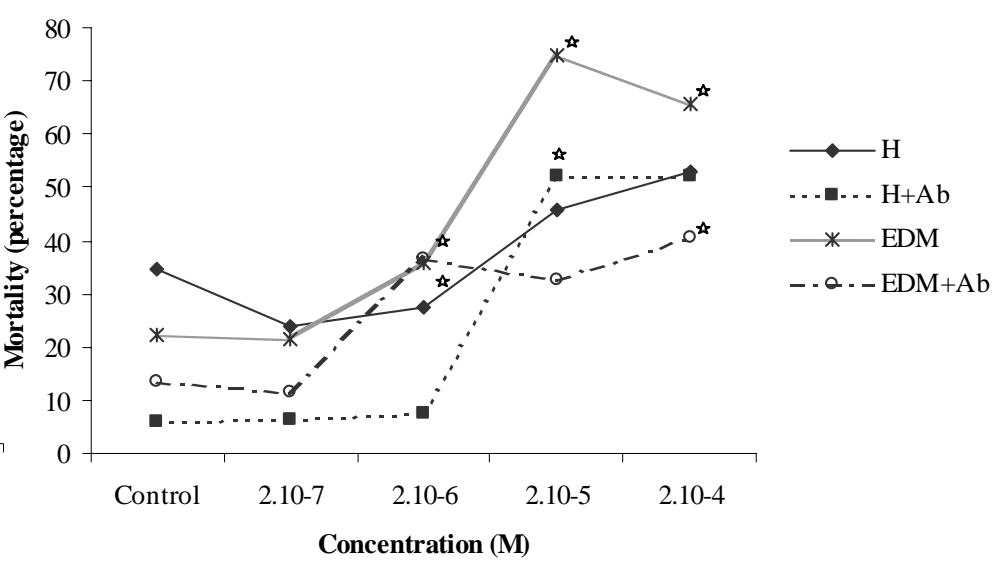

5.b : Results after $24 \mathrm{~h}$ of incubation. 